\title{
Agritourism Development Model Based on Local Wisdom in Karangtengah Village Imogiri Bantul DIY
}

\author{
Sriyadi ${ }^{1, *}$, Eni Istiyanti $^{1}$ \\ ${ }^{1}$ Department of Agribusiness, Faculty of Agriculture, UMY, Indonesia
}

\begin{abstract}
This study aims to explain the agritourism development model strategy based on local wisdom in Karangtengah Village. The research was conducted by interviewing farmers and related parties and the field observation. The results showed that the development of local-wisdom based agritourism required a proper planning and master plan, optimization of the potential owned, cooperation with various parties (private, government and community), education training on tourism to managers and communities, and overall socialization to the community based on community empowerment. It is recommended to optimize the existing potential in cooperation with various parties from the government, the private sector, and universities.
\end{abstract}

\section{Introduction}

Sustainable development is a process covering the economic dimension, social, cultural, and ecology-environment. This process is considered as the whole coverage for the development both in urban and rural areas. However, in most developing countries, the rural population decreases, while land farming begins to lose productivity. These circumstances become a significant factor in the increase in rural poverty, and causing problems such as loss of deforestation, erosion, and productivity, along with the misuse of natural resources. On the other hand, the damage of natural resources causes an issue, such as migration, poverty, and extreme food [1].

The development of agriculture-based rural areas is increasingly encouraged in various regions. This activity aims to develop the potential in rural areas, which, over some time, had previously experienced inequality in regional development. In the past, the development was prioritized for many urban areas, and that rural areas lagged in all sectors, especially for the agricultural industry, even though the farming sector dominated the rural areas. Limited land caused small-scale farming to be inefficient, leading to law farmers' income. These conditions can decrease the motivation of rural communities to focus on the agricultural sector.

In terms of anticipating and developing rural areas, the government currently intensifies rural economic and social development, including rural agribusiness development and rural agritourism program. The purpose of agro-tourism is to increase the necessities of life, create jobs and increase development in rural areas both economically and socially $[2,3,4]$.

\footnotetext{
* Corresponding author: sriyadi@umy.ac.id
} 
Agrotourism should be an integrated part of government programs that aimes to introduce and improve the welfare of rural communities [5]. Agrotourism is one form of tourism that consists of agricultural products, with a variety of recreational facilities which can reduce the tide of urbanization and advance the economy of rural communities [6]. Rural tourism is primarily a way of solving social problems of the village and supporting farmers [7]. The rural agribusiness development aims to increase the added value of agricultural products that can be expected to increase the farmers' income. Agritourism is one of the ways to develop agriculture in rural areas as there are several difficulties in the development of the large-scale agricultural sector, and the potential of the rural regions that are likely to attract tourists [8]. The village has great potential in the application of agro-tourism [9]. The condition also occurred in Karangtengah Village, Imogiri Bantul, currently developed to be agritourism areas; thus, the village placed the third runner-up at the national rural tourism in 2012. This potential is currently developed thoughtfully to improve the welfare of farmers and become a pioneer of agritourism in other not well-managed areas.

Karangtengah Village is highly interesting to develop as it has a variety of potential that can attract tourists. This village is located on the tourist route from Yogyakarta downtown toward the tombs of Mataram Kings and Parangtritis Beach. Agricultural land in Karangtengah Village is dominated by rice and horticulture, and almost all communities have farming fields due to the availability of irrigation dams and fertile soil conditions. In addition to rice farming, the community has also developed in animal husbandry and livestock waste processing into organic fertilizer and has developed organic agriculture. The agricultural processing business has been established in the form of a handicraft home industry and culinary.

The social community is highly enthusiastic about developing rural areas, especially for the development of agritourism. Furthermore, the areas have frequently been visited by domestic and foreign tourists. Government institutions and farmer groups are hugely supportive of agritourism as the village is one of the agro-politan development areas in Bantul Regency.

However, this agro potential should be developed because the number of tourists/visitors is still lower than in other regions in the tourism areas in Yogyakarta Special Region. Tourism visits in Bantul Regency are still dominated by the particular coastal area, especially Parangtitis Beach. Meanwhile, tourism revenue in Bantul Regency in 2010 only reached $5.41 \%$ [10]. Based on the issue mentioned above, it is necessary to conduct a more in-depth study of the region condition, especially the one illustrating the weaknesses and shortcomings to support agritourism, and how the community responds to the development of agritourism itself in the context of community empowerment. This study aims to identify the agritourism development model suitable for the farmers' empowerment in Karangtengah Village, Imogiri District, Bantul Regency, Yogyakarta Special Region by prioritizing local wisdom.

\section{Research Method}

\subsection{Research Object and Sampling Technique}

Descriptive research $[11,12,13,14]$ on the model of agritourism development based on local wisdom in Karantengah Village Imogiri Bantul was conducted using survey research to farmers or agribusiness and parties related to the agritourism. Karangtengah Village is a tourism area with an award as the third runner-up in the national tourism village in 2012 . The village consists of six hamlets - most of the people work in the farming and domestic industries. Samples of farmers/agribusiness actors were collected from each hamlet through 
a proportional random sampling comprising 100 respondents. The data were collected by conducting observations and interviews according to the questionnaire guide.

\subsection{Analysis Technique}

A SWOT analysis was utilized to formulate a model of local wisdom-based agritourism development in Karangtengah Village. This analysis was used by scrutinizing the present condition and reviewing the strengths, weaknesses, opportunities, and threats. The SWOT analysis of the potential of local wisdom-based agritourism development in the Karangtengah Village Imogiri showed several strengths, weaknesses, opportunities, and threats, which then revealed the strategies as a guide in determining the program for the development of agritourism in Imogiri.

SWOT is a tool that can be used to analyze qualitatively. Rangkuti [15] mentions that SWOT analysis is the systematic identification of various factors to formulate a policy strategy. This analysis is based on the logic that can maximize strengths and opportunities but simultaneously can minimize weaknesses and threats.

\section{Results and Discussion}

\subsection{The Model of Agritourism Development based on Local Wisdom in Karangtengah Green Village}

The agritourism development based on local wisdom concerns tourism development and following the conditions of sustainable development, as stated by [16]. The agritourism development based on the local wisdom at the Karangtengah village utilized the seven-step plan consisting of (1) formulating the problems, (2) determining the objectives, (3) analyzing the condition, (4) searching for alternatives, (5) selecting the best alternative, (6) assessing the selected alternative (7) implementing the program [16], quoted from Boothroyd). The use of this approach was expected to produce a model of ecotourism development based on local wisdom in Karangtengah Village.

\subsubsection{Formulating the Problems.}

Based on the identification of the research location, the following issues were formulated:

a. The government of Bantul has appointed Karangtengah as a Tourism Village. However, it has not had a standard pattern for developing the existing potential.

b. The lack of commitment from the government of Imogiri District and Karangtengah Village in developing the tourism area causes the managers of Karangtengah Tourism Village are not in synergy with their policies.

c. The society supports tourism development in Karangtengah Village with the concept of agritourism development based on local wisdom. However, people are still in doubt about the government of Bantul Regency, Imogiri District, and Karangtengah Village to help manage and develop this tourism village.

\subsubsection{The purpose Determination of Agritourism Development based on Local Wisdom.}

The objectives of the agritourism development based on local wisdom at the Karangtengah village are as follows:

a. Searching for alternatives to agritourism development that can be developed following 
the potential of Karangtengah Village. Thus, in the future, agritourism development based on local wisdom can be implemented based on environmental ethics to benefit the community.

b. Developing agritourism must continue to be guided by tourism based on environment and local wisdom. Thus, the existing natural potential can still be utilized sustainably.

c. Empowering local communities can be achieved by enlarging new job vacancies and opportunities for the community to become permanent employees.

d. Establishing new tourism objects and attractions through agro-cultivation objects with a variety of artificial attractions or "multi tourism attractions". This program has been successfully developed in several regions with a similar climate and type of soil to Karangtengah Village.

\subsubsection{Analysis of the Condition.}

Analysis of internal and external conditions was written into the SWOT matrix. This matrix can clearly describe how the opportunities and external threats faced can be adjusted according to their strengths and weaknesses [15]. The SWOT matrix is presented in Table 1 below:

Table 1. SWOT Matrix

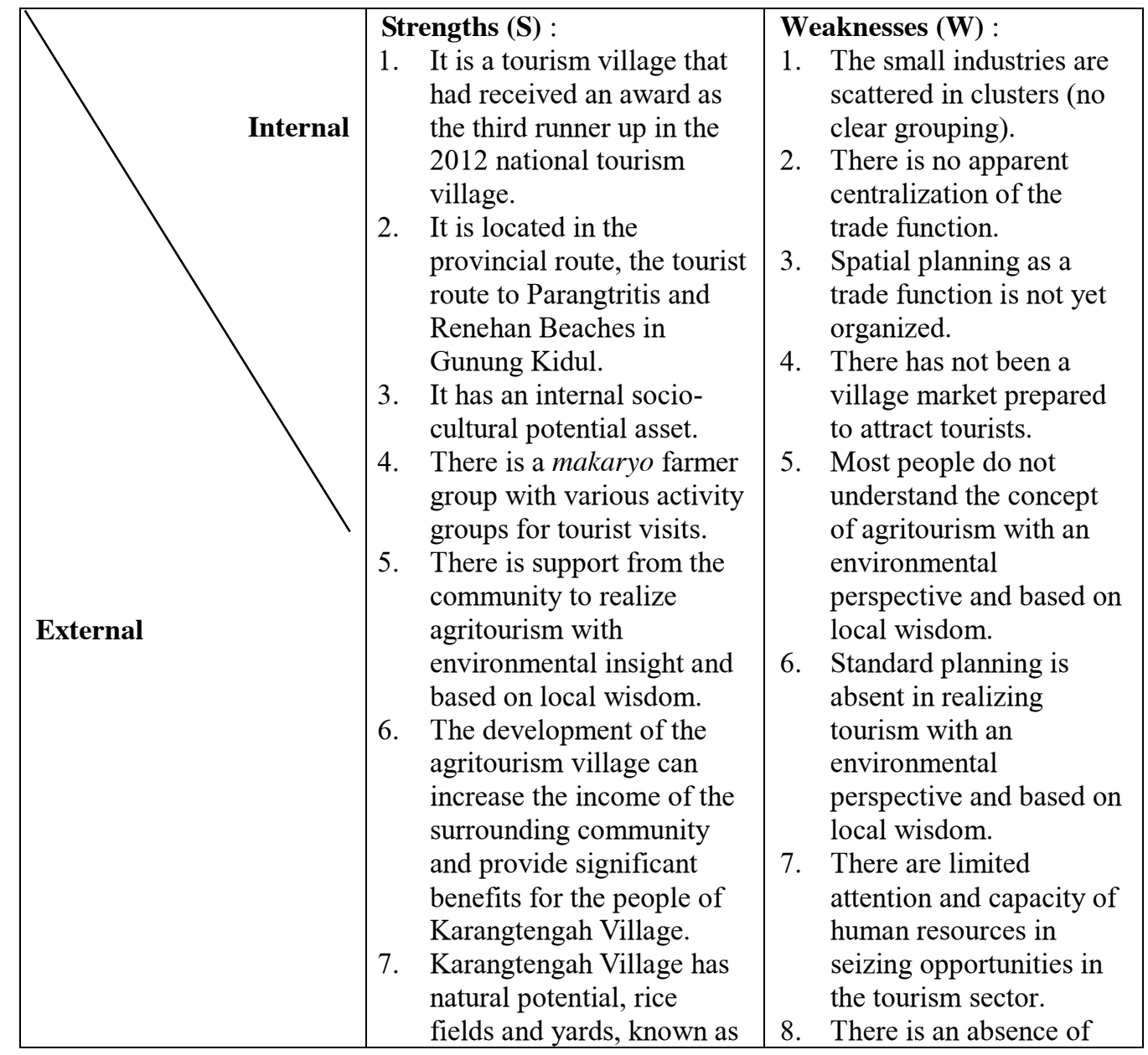


a fertile village due to water available all year round from the Opak River emptying from Mount Merapi, and traditional farming management. If agritourism is built with an environmentally sound concept and based on local wisdom, then it will be easy to bring in tourists, making it easier to increase its status from being a village to becoming a tourist destination village.

8. The strategic location of Karangtengah Village, located in the tourist area of "Mangunan Fruit Garden - Cerme Cave Tombs of the Imogiri Kings - Parangtritis Beach" having a beautiful panorama and rural atmosphere will be another attraction besides the development of environmentally sound and based agritourism local culture.

9. It has accessibility (good road access), making it easier for visitors to get to tourist sites.

10. There are several wellknown tourist objects around Karangtengah Village, such as Cerme Cave, Tombs of the Mataram Kings, Pajimatan Batik Village, Mangunan Fruit Garden, Mbecici Peak, Upper Cloud Palace, and Pelem Madu Culinary Village. Those wanting to visit one of these tourism objects are expected to stop at the agritourism area with an environmental perspective and based on local wisdom. human resources having the ability to develop tourism.

9. There is a tendency for unsustainable tourism management.

10. There is a tendency for agro-cultivation to be not environmentally sound and based on local wisdom.

11. There is a lack of adequate financial support for sustainable tourism development.

12. The formulation of the tourism program is still piecemeal, such as the Karangtengah Tourism Village development plan, only up to the preparation of a master plan book and detailed engineering.

13. There is a desire to directly build a tourist attraction into a big one, not done in stages with proper planning.

14. The local community does not know the steps in developing tourism potential, especially the development of agrocultivation.

15. Excessive tourism development can cause less attention to the environment and local wisdom. 
11. It has brown and dark brown latosol soil types with various types of plants, making it easy to cultivate agritourism.

12. The livelihoods of the people are mostly agricultural, which will facilitate the development of agro-cultivation.

13. Local people maintain the functions of the land as it is intended. It is known from the comments of respondents that they are committed to protecting or maintaining their land for agriculture.

14. The existence of paddy fields, gardens or yards, and water sources are preserved. Thus, they continue to function as a local hydrological balance.

15. It has art studios that can be developed as an attraction for tourists.

16. The existence of various small industries, both handicrafts, and local food processing, is one of the attractions for tourists.

17. The nameplate showing secretarial locations and strategic secretarial locations make it easier for tourists to go to agritourism locations.

18. There are homestay facilities with rural nuances attractive to tourists.

19. The people have a willingness to use their houses as homestays for tourists, thus increasing their income. 


\section{Opportunities (O) :}

1. There is support from the Bantul Regency

Tourism Office to realize local wisdombased agritourism.

2. There is support from hotels and inns in Yogyakarta City to promote

Karangtengah Tourism Village.

3. There is support from travel agencies to promote Karangtengah Tourism Village.

4. There is an opportunity to offer rural conditions to urban communities as an alternative to tourism.

5. There is a transfer of technology from outside for the tourist village development.

6. It provides education and training for the community as workers in the tourism sector.

7. It opens up new job opportunities.

\section{Strategies S/O :}

1. Developing agritourism environmentally sound and based on local wisdom in collaboration with the Bantul Regency Tourism Office

2. Utilizing the potential of fertile land, panoramic views, rice fields, and yards as well as internal socio-cultural potential assets to support the development of agritourism in Karangtengah Village

3. Optimizing the existing tourism objects, the position, and strategic location of the village so that Karantengah Tourism Village can genuinely become a tourist destination is of interest to the community.

4. Improving the functions of existing facilities and infrastructure, such as easy access, signboards, and transportation means developing agritourism based on local wisdom.

5. Collaborating with tourist agencies, hotels and lodging managers to introduce the city community to agritourism in Karangtengah Tourism Village.

6. Requiring transfer of technology to develop the potential of the existing local handicraft and food processing industry

7. Involving the local community to become professional personnel in managing assets and potential in Karangtengah Tourism Village so that agritourism development

\section{Strategies W/O :}

1. Involving the tourism office of Bantul Regency and the related government by involving representatives of the surrounding community to make a clear master plan and detailed stages in the development of Green Village Agritourism of Karangtengah Tourism Village

2. Optimizing agritourism management in collaboration with business people (hotel and lodging owners), travel agents, and tourism object managers to organize agritourism facilities and optimize the management

3. Providing education and training to the community to prepare more professional human resources in developing agritourism with an environmental perspective and based on local wisdom to open up new job opportunities

4. Submitting a budget proposal for agritourism development to the local government

5. Conducting a comparative study from local community representatives who will manage agritourism with local governments to other areas that have successfully developed agritourism 


\begin{tabular}{|c|c|c|}
\hline & $\begin{array}{l}\text { can go according to the } \\
\text { plan } \\
\text { 8. Improving coordination } \\
\text { with other related parties } \\
\text { such as managers of } \\
\text { tourism objects around } \\
\text { Karangtengah Tourism } \\
\text { Village, local communities } \\
\text { and farmers for a more } \\
\text { integrated agritourism } \\
\text { management }\end{array}$ & \\
\hline $\begin{array}{l}\text { Treats (T) : } \\
\text { The government's } \\
\text { seriousness of } \\
\text { Bantul Regency, } \\
\text { Imogiri District, and } \\
\text { Karangtengah } \\
\text { Village has not been } \\
\text { optimal in dealing } \\
\text { with tourism. } \\
\text { The presence of } \\
\text { tourists will } \\
\text { influence changes in } \\
\text { local community } \\
\text { behavior. } \\
\text { The emergence of } \\
\text { many tourist villages } \\
\text { in Bantul Regency, } \\
\text { Yogyakarta Special } \\
\text { Region } \\
\text { Promotions carried } \\
\text { out by other tourist } \\
\text { villages } \\
\text { Policymakers in the } \\
\text { government of } \\
\text { Bantul Regency, } \\
\text { Imogiri District, } \\
\text { Karangtengah } \\
\text { Village have not } \\
\text { understood the } \\
\text { concept of } \\
\text { agritourism } \\
\text { development } \\
\text { environmentally } \\
\text { sound and based on } \\
\text { local wisdom. } \\
\text { 5. }\end{array}$ & $\begin{array}{l}\text { Strategies } \mathbf{S} / \mathbf{T} \text { : } \\
\text { 1. In the face of competition } \\
\text { with the emergence of } \\
\text { tourist villages, reforms or } \\
\text { arrangements of the Green } \\
\text { Village Agritourism of } \\
\text { Karangtengah Tourism } \\
\text { Village are carried out by } \\
\text { optimizing existing } \\
\text { potential and facilities, } \\
\text { then carrying out effective } \\
\text { promotions in } \\
\text { collaboration with related } \\
\text { agencies. } \\
\text { 2. Optimizing the role of } \\
\text { local government in } \\
\text { understanding the concept } \\
\text { and handling of assets } \\
\text { owned by Karangtengah } \\
\text { Tourism Village to } \\
\text { develop agritourism with } \\
\text { environmental insight and } \\
\text { local wisdom-based } \\
\text { The concept of agritourism } \\
\text { development in the } \\
\text { Karangtengah Tourism } \\
\text { Village does not leave } \\
\text { local wisdom and ethics in } \\
\text { the local community }\end{array}$ & $\begin{array}{l}\text { Strategies W/T : } \\
\text { 1. The maturation of the } \\
\text { agritourism development } \\
\text { concept with an } \\
\text { environmental } \\
\text { perspective and based on } \\
\text { local wisdom involve all } \\
\text { stakeholders and } \\
\text { community } \\
\text { representatives. } \\
\text { 2. The agritourism } \\
\text { development plan is } \\
\text { carried out in stages } \\
\text { without abandoning the } \\
\text { principles of } \\
\text { sustainability and } \\
\text { environmental ethics. } \\
\text { There is a socialization } \\
\text { of the Karangtengah } \\
\text { Tourism Village } \\
\text { Agritourism } \\
\text { development plan to all } \\
\text { local communities. }\end{array}$ \\
\hline
\end{tabular}




\subsubsection{Searching for Alternatives.}

The alternative solutions to problems in agritourism development efforts include:

a. Developing agritourism based on local wisdom in collaboration with the Bantul Regency Tourism Office

b. Utilizing the potential of fertile land, panoramic views, rice fields, and yards as well as internal socio-cultural potential assets to support the agritourism development in Karangtengah Tourism Village

c. Optimizing the existing tourism objects, the position, and strategic location of Karangtengah Tourism Village so that this village can genuinely become a tourist destination of interest to the community

d. Improving the function of existing facilities and infrastructure such as easy access, signboards, and transportation in developing agritourism based on local wisdom

e. Collaborating with tourist agencies and hotel and lodging managers to introduce the city community to agritourism in Karangtengah Tourism Village

f. Requiring technology transfer to develop the potential of the existing local handicraft and food processing industry

g. Involving the local community to become professional staff in managing assets and potential in Karangtengah Tourism Village, thus agritourism development can go according to plan. To develop agro-tourism requires the support of all parties, especially the local community $[17,18]$

h. Improving coordination with other related parties such as the manager of tourism objects around Karangtengah Tourism Village, local communities, and farmers for more integrated agritourism management

i. Involving the Bantul Regency Tourism Office and the related government by involving representatives of the surrounding community to make a clear master plan and detailed stages in the agritourism development of the Karangtengah Tourism Village

j. Optimizing agritourism management in collaboration with business people (hotel and lodging owners), travel agents, and tourism object managers to organize agritourism facilities and optimize the management

k. Providing education and training to the community to prepare more professional human resources in developing agritourism based on local wisdom to open up new job opportunities

1. Submitting a budget proposal for agritourism development to the local government

$\mathrm{m}$. Conducting a comparative study from local community representatives who will manage agritourism with local governments to other areas that have succeeded in developing agritourism

n. In the face of competition with the emergence of tourist villages, reforms or arrangements of the Karangtengah Tourism Village agritourism are carried out by optimizing existing potentials and facilities, then performing effective promotions in collaboration with related agencies.

o. Optimizing the role of the local government in understanding the concept and handling of assets owned by Karangtengah Tourism Village to develop agritourism with an environmental perspective and based on local wisdom

p. The concept of agritourism development in Karangtengah Tourism Village does not leave local wisdom and ethics in the local community.

q. The maturation of the agritourism development concept with an environmental perspective and based on local wisdom involve all stakeholders and community representatives.

r. The agritourism development plan is carried out in stages without abandoning the principles of sustainability and environmental ethics. 
s. There is a socialization of the Karangtengah Tourism Village Agritourism development plan to all local communities.

\subsubsection{Selecting the Most Appropriate Alternatives.}

The best alternatives that should be performed were selected based on the predetermined alternatives, which include:

a. Optimizing the potential of existing tourism objects, fertile land, panoramic views, rice fields, yards, strategic position and location, as well as internal socio-cultural potential assets so that Karangtengah Tourism Village can genuinely become a tourist destination of interest to the community. The tourism models that should be developed in Karangtengah Tourism Village are environmentally friendly tourism, marketing of natural potentials such as rice fields, gardens, and types of plants and small industries, packed together with multi-tourist attractions. Therefore, they are integrated into one area-agritourism based on local wisdom. Cultural and historical features that create ideal conditions for the development of rural tourism [19].

b. To make a plan and master plan, it is necessary to involve various related parties (the Bantul Regency Tourism Office and related government), the private sector, and representatives of the surrounding community without leaving local wisdom and ethical order of the local community and by adhering to the principles of being open and honest. The government acts as a facilitator, the private sector as executor of development by involving the community, in collaboration with entrepreneurs who have successfully developed agritourism. The government of Bantul Regency can invest its shares. The financial audit is carried out by a public accountant.

c. Optimizing agritourism management based on local wisdom in collaboration with various parties such as community, government, business people (hotel and lodging owners), and travel agents. In Sri Lanka, agro-tourism is flourishing thanks to government intervention [20].

d. Providing education and training to the community to prepare more professional human resources in developing agritourism based on local wisdom to open up new job opportunities

e. It is necessary to thoroughly socialize the agritourism development plan based on local wisdom to all communities in Karangtengah Tourism Village.

\subsubsection{Assessing Selected Alternatives}

The alternatives above were chosen to realize agritourism based on local wisdom, having different characteristics from agritourism developing in other areas. Moreover, working with agritourism entrepreneurs who have achieved success will facilitate its management.

\subsubsection{Proposed Strategy}

To realize the best alternative in realizing agritourism, it is necessary to:

1. Building Environmentally Friendly Agritourism Objects

a. Planning

It is necessary to have proper planning to build agritourism objects. First, the steps to be taken include planning an agritourism area by determining a location that meets the criteria following the objectives of agritourism development. The next step is to explore the potential and formulate the steps for its establishment and development. 
b. Making a master plan

Making a master plan should involve various related parties (the Tourism Office of Bantul Regency and related government), the private sector, and representatives of the surrounding community without leaving local wisdom and ethical order of the local community by adhering to open and honest principles. The government acts as a facilitator, the private sector as executor of development by involving the community, in collaboration with entrepreneurs who have successfully developed agritourism.

c. Management of eco-friendly tourism objects

Managers must fully understand what can be highlighted and which are the characteristics of the object by ensuring environmental sustainability and sustainability, for example, the elements of the arrangement, the number of collections, production, cultivation technology (organic agriculture), historical value, natural beauty, and agrarian culture. Through the object's uniqueness, visitors are expected to obtain a deep and unforgettable impression.

d. Visitor management

Managing tourism and manufactured products, in general, recognizes what is called the product life cycle. It means that at certain times with the increasing flow of tourist visits, these products will experience saturation and are no longer attractive to visit. Before reaching this point, the management should act early to reduce saturation, one of which is changing the arrangement and appearance of the room. Management must prioritize visitor satisfaction [21]. Managing visitors should consider (1) the concept of attracting visitors, and (2) rules for visitors.

e. Supporting facilities for agritourism based on local wisdom

As a tourist attraction, agritourism should provide convenience for tourists by completing the infrastructure and facilities. Service facilities are established in the proper and strategic locations to make them function optimally. The Karangtengah Tourism Village signboard, located on the street in Panggang, Gunung Kidul - Yogyakarta, is one of the identifiers for Bantul residents and travelers from outside the area. The supporting facilities and facilities owned by Karangtengah Tourism Village are paved roads and signboards to locations, parking lots, information centers, information boards, roads in the agritourism area consisting of vehicle roads and trails, lodgings, research facilities (experimental gardens, plasma gardens), toilets, places of worship, and trash cans. Of these various facilities and infrastructure, some were about to be renewed.

\section{f. Institutional management}

The development of Karangtengah Tourism Village (agritourism) requires the support of all government parties, the private sector, especially agritourism entrepreneurs, related institutions such as travel, hotels and others, universities, and the community. Community really needed assistance both in the field of planning, development and management of agritourism [22][23]. In developing agritourism businesses, three components are quite decisive, namely the government, entrepreneurs or investors, and executors or operational personnel.

\section{Developing Agritourism based on Local Wisdom}

To develop agritourism with an environmental perspective, and based on local wisdom, it is necessary to pay attention to the following:

a. Environmental conservation.

The development of agritourism is expected to have environmental preservation values. With so many trees, besides being able to absorb noise and dust, and hold back the speed of rainwater, it can make the air fresh and comfortable. The existence of trees will have a hydrological function to hold water reserves. Besides, the maintenance of various 
types of plants is useful for preserving the source of cultivated plant germplasm.

b. Aesthetic value and natural beauty

A beautiful and well-ordered natural environment will attract humans. Panorama beauty can be obtained from the topography, the types of plants and the shape of the buildings arranged in a spatial layout in harmony with nature. Each agritourism object is strived to have its aesthetic appeal, with its characteristics. The building shape complementing the agritourism location is designed in such a way so as not to reduce its beauty value but strives to appear to be one with nature. Therefore, in making agritourism, it is necessary to have proper layout planning, building architecture, and landscape. Striving for sanitation placement is close to visitor activities. Cleanliness, as an element of beauty, should also be considered. The provision of dry and wet waste can be placed in strategic places.

c. Recreational value

Agritourism, as a tourism object, is inseparable from recreational activities. Recreation in a beautiful and comfortable natural environment will have a value of satisfaction of its own. As a place of recreation, in an agritourism environment, it is necessary to create supporting facilities or event packages that can create joy amid nature. Tourists wanting to experience planting or reaping rice can go down to the fields together with farmers. Those having a fishing habit will be able to channel their hobbies through fisheries agritourism packages. Undoubtedly, all the entertainment packages offered must not endanger the preservation of nature and visitors.

d. Center for scientific activities and development

Agritourism is not only a means of entertainment but also a place to conduct research or knowledge development. The richness of plants in the agritourism area invites curiosity from students, students, researchers, and scientists. Agro-tourism is a place to learn, because visitors can learn about farming with farmers [24]. With the presence of agritourism based on local wisdom, it will be beneficial for those who always want to increase their knowledge.

Management and quality improvement of agritourism can be carried out in collaboration with research or educational institutions. This cooperation will be useful for both parties. Agritourism managers provide research facilities and places, while researchers can contribute their research results for science development. Likewise, students studying in agro-areas at the same time can help manage various activities within the area and gain additional knowledge.

e. Economic benefits

The development of a tourism or agritourism village based on local wisdom would increase economic growth for the community, either directly or indirectly. The flow of goods and services that occurs would open up opportunities for economic transactions. The circulation of goods and services is expected to provide benefits for the community in the form of:

(1) Opening up employment opportunities

(2) Increasing community income

(3) Increasing regional popularity

(4) Increasing production

(5) Creating an Agro City in Bantul Regency

f. Development in stages

Funds are required to realize agritourism. The fund size depends on the object to be created. Suppose agritourism is to be built based on local wisdom. In that case, it can be started from a small-scale business, gradually be developed into a broader direction 
accompanied by proper planning, the honesty of the managers, and the spirit of building agritourism as a projection for the future. Projection to the future contains efforts to increase or decrease a condition existing at present. Based on scientific considerations, with structured planning, it is expected to achieve effective and efficient results.

Thus, agritourism is not solely business in the service sector for the fulfillment of consumers for beautiful scenery and fresh air, but can also act as a media for promoting agricultural products, becoming a media for public education, and providing opportunities for the development of diversified agribusiness products. In other words, it can also become a new growth area for agricultural areas. Thus, agritourism can become a new source of growth for the region from the agricultural tourism sector.

\section{Conclusions and Recommendation}

\subsubsection{Conclusions}

The following conclusions were drawn based on the research results:

a. The SWOT analysis results showed that agritourism development required a proper planning and master plan, optimization of its potential, cooperation with various parties (private, government, and community), training education on tourism to managers and the community, and overall socialization to society.

b. Based on various potentials, the agritourism development model was to apply an agritourism model based on local wisdom, processing available natural resources by involving the local community.

\subsubsection{Recommendation}

Based on the research results, the following recommendations can be put forward in the framework of developing agritourism:

a. The government, especially the Tourism Office and the Bantul Regency Agriculture Office, should provide more comprehensive and sustainable motivation, training education, and assistance.

b. Managers should further optimize the existing potential by involving the wider community.

c. The community should be more actively involved in it by optimizing its potential.

d. Private companies should invest in the development of agritourism in Karangtengah Tourism Village.

e. Researchers should be directly involved in it by conducting research, for example, researching the development of small and handicraft industries.

\section{References}

1. Akpinar, et.al, Kluwer J. 6, 473-486 (2004)

2. Budiawarjono \& Wardiningsih, S, Perencanaan Lanskap Agrowisata Berkelanjutan Kawasan Gunung Leutik Bogor. Jurnal Arsitektur NALARs. 12(2).1-10 (2013)

3. Bwana, M.A., Olima, W.H.A., Andika, D. Stephen G. Agong \& Hayombe, P,. Agritourism: Potential Socio-Economic Impacts In Kisumu County. Journal Of Humanities And Social Science (IOSR-JHSS). 20(3).78-88 (2015)

4. Wyporska, K., \& Mosiej, J, Technical Infrastructure For Environmental Protection At The Level Of Farms As A Factor Of Sustainable Rural Slamet Ifandi, Yustika Aulia 
Rahma / Biosaintifika 12 (3) (2020): 335-342 342 Development. Journal Economic and Environmental Studies.10(1).71-84 (2010)

5. Kambey, H.J.,Sasmito Djati, M.,Polii B, \& Hakim, L., The development of Tampusu agrotourism area in North Sulawesi, Indonesia. Journal of Environmental Science, Toxicology and Food Technology (IOSR-JESTFT). 10(7).50-55 (2016)

6. Khotibul, U., Siti, K., \& Mohammad, Z., Strategy for Water Guava Agro-Ecotourism Development in Camplong District, Sampang Regency. Scientific Agroinfo Student Galuh, 6(3), 457-469 (2019)

7. Evgrafova L V, Dynamic properties and economic efficiency of the formation of rural tourist destinations, International Scientific Journal 2, 37-41 (2019)

8. Arifin M. et.al, J. Il. Pert. 32 (2007)

9. Sevgi T.R, An application of a women-oriented agro-tourism rural development model in improving local economy. African Journal of Business Management Vol. 5(22), pp. 9714-9723 (2011)

10. BPS Bantul (2011)

11. Sugiyono, Metode Penelitian Kuantitatif Kualitatif dan $R \& D$ (2014)

12. Galo, W., Metode Penelitian (2012)

13. Nasution, Metode Research (Penelitian Ilmiah) (2010)

14. Nazir, M., Metode Penelitian (1999)

15. Rangkuti, Freddy, Analisis SWOT Teknik Membedah Kasus Bisnis (2015)

16. Hadi dan Akwiwu, JASR. 51 (2005)

17. Siwi Harning Pambudi, Sunarto, Prabang Setyono. Agro-Tourism Development Strategy in Desa Wisata Kaligono (Dewi Kano) of Kaligesing District of Purworejo Regency. Agriekonomika Volume 7, Nomor 1, (2018)

18. Vitasurya, V. R., Local Wisdom for Sustainable Development of Rural Tourism, Case on Kalibiru and Lopati Village, Province of Daerah Istimewa Yogyakarta. Procedia Social and Behavioral Sciences 216 (October 2015): 97-108 (2016)

19. Evgrafova LV., Problems of organizational and economic efficiency of the dairy cattle industry in the conditions of scientific and technological progress . Proc., Int., Conf (Moscow) pp 49-52 (2014)

20. Pushpa Malkanthi, Jayant K. Routray, ASEAN Journal on Hospitality and Tourism, 10, 3-16 (2011)

21. Indah Arum Ganestyani, Jamhari, Masyhuri, Journal of Applied Management (JAM) 172, 217-226 (2019)

22. I Ketut Sumantra, Anik Yuesti, AA. Ketut Sudiana, Australian Journal of Basic and Applied Sciences, 1113, 93-99 (2017)

23. I Wayan Budiasa and I Gusti Agung Ayu Ambarawati, Journal of ISSAAS, 20, 29-40 (2014)

24. Petroman, I., Varga, M., Claudia, E., Petroman, C., Momir, B., Turc, B., \& Merce, I., Agritourism : An Educational Tool for the Students with AgroFood Profile. Procedia Economics and Finance 39, 83-87 (2016) 